\title{
THE FOUNTAINWELL DRAMA TEXTS
}

\author{
General Editors \\ T. A. DUNN \\ ANDREW GURR \\ JOHN HORDEN \\ A. NORMAN JEFFARES \\ R. L. C. LORIMER \\ Assistant General Editor \\ BRIAN W. M. SCOBIE \\ 10
}

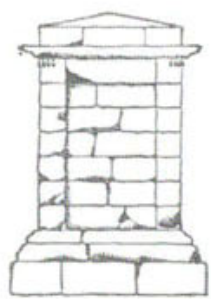





\section{PHILIP MASSINGER \\ and \\ NATHAN FIELD}

\section{THE FATAL DOWRY}

Edited by

T. A. DUNN

UNIVERSITY OF CALIFORNIA PRESS

Berkeley and Los Angeles • 1969 


\section{University of California Press}

Berkeley and Los Angeles, California

First Published 1969

Library of Congress Catalog Card No.: 69-19073

Originally published by Oliver and Boyd Ltd,

Edinburgh, Scotland

(C) 1969-Critical Introduction, A Note on the Text, Text as printed, Textual Notes, Commentary,

Bibliography, and Glossary-T. A. Dunn

Printed in Great Britain 


\section{ACKNOWLEDGMENTS}

This edition was prepared during a year spent as Visiting Professor in the University of Western Ontario. I would extend my grateful thanks to the University and the Department of English for making my work possible, and in particular to Professor Herbert Berry and Dr E. J. Devereux for much helpful advice. My thanks are also due to John Horden and Brian Scobie for supervision of this edition, for much kindness and encouragement, and for freely giving of their time and experience.

Stirling

T. A. DunN

2 May 2968 
